\title{
Diversitas Suku Agamidae (Reptilia: Squamata) pada Berbagai Tipe Habitat di Kawasan Pertambangan Emas Martabe, Sumatera Utara: Dalam Tahap Konstruksi
}

\section{Diversity of Agamid Lizards (Reptilia: Squamata) in Different Habitat Types in Martabe Gold Mining-North Sumatera: during Construction Phase}

\author{
Awal Riyanto \\ Bidang Zoologi (Museum Zoologicum Bogoriense), Puslit Biologi-LIPI \\ Gedung Widyasatwaloka, Jl. Raya Jakarta Bogor Km.46 Cibinong 16911 \\ E-mail:awal_lizards@yahoo.com danawal.riyanto@lipi.go.id
}

\begin{abstract}
A study of Agamid lizards diversity and their distribution surrounding Martabe Mining project Area, South Tapanuli, North Sumatera was conducted in five different habitat types. The data were gathered by opportunistic searching in each habitat type with two replications. ShannonWiener index was used to determine the diversity while the homogeneity was verified by Pielou index. The similarity of Agamid communities among habitat types was confirmed by Sorensen coefficient. As a result, 9 Agamid species were recorded with Draco melanopogon as the major component of Agamid community making up $49.1 \%$ of total individuals gathered. Highest diversity occurred in moderately disturbed forest, but the most homogeny took place in riparian lowland forest. The cluster analysis using Sorensen's coefficient of agamid species distribution among habitat types distributed the habitats into three major groups, with the most similarity occurred between primary and riparian lowland forests $(\mathbf{7 5 \%})$. The identification key of the species was made.
\end{abstract}

Key words: Agamid, diversity, distribution, habitat, Martabe

\begin{abstract}
Abstrak
Telah dilakukan penelitian mengenai diversitas dan distribusi suku Agamidae pada lima tipe habitat di kawasan Pertambangan Emas Martabe, Tapanuli Selatan. Data diperoleh melalui pencarian secara oportunis (aktif) yang dilakukan dua kali pengulangan di setiap tipe habitat. Diversitas tiap-tiap tipe habitat ditentukan dengan dengan nilai indeks Shannon-Wiener, adapun kemerataannya ditentukan dengan perhitungan indeks Pielou. Kekerabatan komunitas antar tipe habitat ditentukan melalui nilai koefisien Sorensen. Hasil penelitian menunjukkan bahwa 9 spesies Suku Agamidae dapat ditemukan pada kawasan pertambangan emas Matabe, dengan Draco melanopogon sebagai komponen utama penyusun komunitas suku Agamidae $\mathbf{( 4 9 , 1 \%}$ dari jumlah total individu). Diversitas tertinggi terdapat pada tipe habitat hutan terganggu ringan tetapi kemerataan persebaran jenis tertinggi justru terdapat pada hutan dataran rendah riparian. Berdasarkan sebaran jenisnya, kelima tipe habitat yang diteliti mengelompok menjadi tiga kelompok tipe habitat dengan kesamaan komunitas tertinggi terjadi antara hutan primer dan hutan dataran rendah riparian, yaitu $75 \%$. Kunci identifikasi kesembilan jenis anggota Suku Agamidae di kawasan pertambangan emas Martabe selalu dibuat.
\end{abstract}

Kata kunci: Agamidae, diversitas, distribusi, habitat, Martabe

Diterima: 21 Oktober 2009, disetujui: 25 Mei 2010

\section{Pendahuluan}

Dalam pengembangan kebijakan dan pengelolaan lingkungan yang berkelanjutan terutama pada sumberdaya yang terbatas, dibutuhkan adanya pengetahuan mengenai biodiversitas dan organisasi komunitasnya (Gillespie et al., 2005). Jumlah dan persebaran satwa liar dapat digunakan untuk menentukan kealamian suatu hidupan liar. Satwa liar 
merefleksikan kondisi ekologi dan perubahannya dari waktu ke waktu (Wiratno et al., 2001; Pattiselanno, 2006).

Amfibia dan reptilia adalah kelompok satwa liar yang dimanfaatkan sebagai indikator perubahan kondisi ekosistem hutan. Amfibia dan reptilia (herpetofauna) mempunyai peran penting dalam ekosistem, baik sebagai predator berarti (significant predator) terhadap invertebrata maupun vertebrata kecil dan disisi lain kelompok satwa ini juga merupakan sumber pakan penting bagi burung dan mamalia (Howell, 2002).

Penelitian tentang diversitas dan persebaran suku salah satu anggota kelompok herpetofauna yaitu Suku Agamidae di berbagi habitat dalam kawasan pertambangan emas Martabe Tapanuli Selatan Sumatera Utara adalah menarik untuk dilakukan. Penelitian ini akan membantu pemahaman kita sejauh mana kawasan pertambangan emas pada tahap konstruksi tetap dapat memberikan habitat yang baik bagi kehidupan kelompok satwa tersebut. Oleh karena itu, penelitian ini bertujuan untuk mendokumentasi diversitas Suku Agamidae dan kekerabatan komunitas di bebrbagai tipe habitat di kawasan pertambangan emas Martabe Tapanuli Selatan-Sumatera Utara saat tahap konstruksi.

\section{Metode Penelitian}

\section{Waktu dan Lokasi Penelitian}

Penelitian telah dilakukan di tujuh lokasi dalam area pertambangan emas Martabe, Tapanuli Selatan, Sumatera Utara dari tanggal 21 Juli hingga 8 Agustus 2008. Kawasan pertambangan ini sebelumnya bernama Newmont Horas Nauli yaitu ketika dalam tahap pra aktivitas eksplorasi. Ketika penelitian ini berjalan, aktivitas pertambangan sedang memasuki tahap konstruksi. Dari ketujuh lokasi yang diteliti, secara garis besar dapat dikelompokkan dalam lima tipe habitat yaitu:

\section{Hutan Primer}

Hutan ini merupakan hutan alam (virgin), vegetasi tingkat pancang mempunyai tinggi berkisar antara 20-50 m, kanopi tertutup penuh sehingga sinar matahari relatif tidak sampai menyentuh lantai hutan, pisisi GPS tercatat $\mathrm{N}$ 170216 S E 507130.

\section{Hutan Hujan Campuran}

Vegetasi tingkat pancang mempunyai tinggi antara 20-80 m, kanopi tertutup tetapi sinar matahari relatif dapat menembus lantai hutan, topografi relatif curam dengan kemiringan antara 25 dan $45^{\circ}, \mathrm{N} 171025$ dan E 508220.

\section{Hutan Terganggu Ringan}

Hutan ini merupakan hutan primer dan campuran tetapi telah mendapat gangguan (terjadi rumpang-rumpang) berupa pembersihan lantai hutan. Sinar matahari dapat mencapai lantai hutan, tetapi skala gangguan masih relatih kecil. GPS tercatat N 170603 E 507281.

\section{Hutan Dataran Rendah Riparian}

Vegetasi tingkat pancang mencapai $50 \mathrm{~m}$, kanopi terbuka pada bagian sepanjang aliran sungai yang bersubstrat bebatuan dan pasir. GPS tercatat N 167903 E 510956.

\section{Perkebunan}

Vegetasi pada area ini berupa tanaman karet dengan lantai kebun ditutupi rerumputan, sinar matahari $100 \%$ mencapai lantai kebun. GPS tercatat N 167949 E 508665.

\section{Cara Kerja}

Pengumpulan data dilakukan melalui teknik pencarian aktif (opportunistic search) yang dilakukan dua kali ulangan pada setiap tipe habitat. Pencarian siang hari dilakukan secara konsisten selama tujuh jam (09.00-15.00 WIB) dan pencarian pada malam selama lima jam (20.00-24.00 WIB). Pencarian aktif ini dilakukan oleh dua orang yang menjelajah setiap tipe habitat dalam durasi waktu yang telah ditentukan tersebut.

\section{Analisis Data}

Derajat keanekaragaman dan kemerataan persebaran jenis ditentukan dengan menggunakan indeks diversitas Shannon Wiener dan Pielou (Ludwig dan Reynolds, 1988). Uji analisis kekerabatan antartipe habitat yang digunakan jenis Agamidae dilakukan dengan uji pengelompokan (cluster analysis) berdasarkan pada nilai koefisien Sorensen dan hasilnya 
dituangkan dalam bentuk dendrogram. Konstruksi dendrogram dilakukan dengan menggunakan program NTSYSpc 2.1 (Rohlf 2000), melalui metode arithemathic averages (UPGMA) (Gillespie et al., 2005)

\section{Indentifikasi dan Nomenklatur}

Taksonomi dan nomenklatur spesimen yang diperoleh mengacu kepada Rooij (1915 dan 1917), Musters (1983) dan Manthey dan Grosmann (1997). Di samping itu, untuk jenis yang meragukan telah dilakukan konsultasi kepada pakarnya (J.McGuire, pers.comm).

\section{Hasil dan Pembahasan}

\section{Komposisi Jenis}

Dari kelima tipe habitat yang diteliti, berhasil tercatat sebanyak 593 individu suku Agamidae yang terdiri atas 9 jenis dan terbagi dalam 5 marga. Pada lokasi pertambangan yang sama yaitu ketika masih tahap sebelum aktivitas eksplorasi di tahun 2003, Kurniati (2007) melaporkan hanya enam jenis yang dijumpai dan terbagi dalam 4 marga. Salah satu penyebab adanya perbedaan temuan ini adalah konsekuensi sifat kelompok herpetofauna seperti penyataan Blomberg dan Shine (1996), bahwa satwa kelompok herpetofauna umumnya bersifat kriptik sehingga sulit untuk dijumpai. Perbandingan jenis Suku Agamidae sebelum aktivitas eksplorasi dan ketika tahap konstruksi disajikan dalam Tabel 1.

Berdasarkan jumlah individu, tampak bahwa Draco melanopogon merupakan komponen utama penyusun komunitas suku agamidae di kawasan pertambangan emas Martabe. Jenis hap-hap ini mencapai 49,1\% dari total jumlah individu semua jenis agamidae yang ditemukan, sedangkan peringkat kedua ditempati jenis Aphaniotis acutirostris (21\%). Hal ini dapat dipahami karena kedua jenis tersebut merupakan jenis hutan baik pada hutan yang sudah terganggu maupun belum, sedangkan dalam penelitian ini empat dari lima tipe habitat yang diteliti adalah kategori habitat hutan. Komposisi Suku Agamidae yang ditemukan di kawasan pertambangan emas Martabe selengkapnya disajikan pada Tabel 2.

Bila dibandingkan dengan temuan saat tahap sebelum aktivitas di tahun 2003 (Kurniati, 2007), kelimpahan jenis D. melanopogon dan $A$. acutirostris di kawasan pertambangan emas Martabe ini relatif tidak mengalami perubahan. Pada kondisi tahun 2003 baik jenis $D$. melanopogon maupun A. acutirostris kelimpahannya dilaporkan sebagai "fairly common" atau dijumpai dalam kisaran 10 hingga 30 individu per hari, sementara dalam penelitian ini untuk $D$. melanopogon di empat tipe habitat masing-masing dijumpai antara 15 dan 29 individu per hari dan A. acutirostris di tiga tipe habitat masing-masing dijumpai antara 10 hingga 15 individu per hari.

\section{Diversitas dan Kemerataan}

Hasil perhitungan nilai indeks diversitas dan kemerataan dari komunitas Agamidae di lima tipe habitat yang diteliti disajikan pada Gambar 1. Indeks diversitas tertinggi terdapat pada tipe habitat hutan terganggu ringan $(1,407)$, diikuti hutan dataran rendah riparian $(1,328)$, hutan primer $(1,074)$, hutan hujan campuran $(0,814)$ dan perkebunan karet/salak $(0,721)$. Kreb (1989) menyatakan bahwa tinggi rendahnya nilai indeks diversitas dipengaruhi keberadaan jenis dan kelimpahan individu tiap jenis tersebut. Pada penelitian ini derajat kemerataan persebaran jenis tertinggi justru terdapat pada hutan dataran rendah riparian $(0,958)$, diikuti hutan terganggu ringan $(0,785)$, hutan primer $(0,775)$, perkebunan $(0,657)$ dan terendah pada hutan hujan campuran (0.587). Hal ini menggambarkan bahwa pada hutan terganggu ringan kaya akan jumlah jenis tetapi dalam hal kemerataan jumlah individu tiap-tiap jenis relatif kurang merata daripada pada tipe hutan dataran rendah riparian. Pada hutan terganggu ringan ditemukan enam jenis dengan jumlah individu tiap-tiap jenis sangat bervariasi yaitu dari 1 hingga 17 individu, sedangkan pada hutan dataran rendah riparian yang hanya ditemukan empat jenis namun persebaran jumlah individunya relatif lebih merata yaitu dari 6 hingga 12 individu (lihat Tabel 2). 
Tabel 1. Perbandingan jenis suku Agamidae yang ditemukan saat sebelum aktivitas ekplorasi dan ketika tahap konstruksi pada area pertambangan emas Martabe, Tapanuli Selatan, Sumatera Utara.

\begin{tabular}{ll}
\hline \hline \multicolumn{2}{c}{ Tahap Aktivitas Pertambangan Emas } \\
\hline \multicolumn{1}{c}{ Sebelum Aktivitas Eksplorasi 2003 (Kurniati, 2007) } & \multicolumn{1}{c}{ Konstruksi 2008 (Penelitian ini) } \\
\hline \hline Aphaniotis acutirostris & Achantosaura armata \\
& Aphaniotis acutirostris \\
Bronchocela cristatella & Bronchocela cristatella \\
Draco maximus & Draco melanopogon \\
Draco melanopogon & Draco obscurus obscrus \\
Draco volans (=Draco sumatranus)* & Draco quinquefasciatus \\
& Draco sumatranus \\
Gonocephalus grandis & Gonocephalus grandis \\
\hline \hline
\end{tabular}

Keterangan: *=Draco volans adalah sinonim Draco sumatranus (komunikasi pribadi, Jimmy McGuire, 2008).

Tabel 2. Komposisi jenis Agamidae yang ditemukan di kawasan pertambangan emas Martabe-Sumatera Utara pada Juli sampai Agustus 2008.

\begin{tabular}{|c|c|c|c|c|c|c|c|}
\hline \multirow{2}{*}{ Jenis } & \multicolumn{5}{|c|}{ Tipe Habitat } & \multirow{2}{*}{$\sum_{\text {Individu }}$} & \multirow{2}{*}{$\begin{array}{l}\text { Persen Terhadap } \\
\text { Total Individu }\end{array}$} \\
\hline & HP & HHC & HTR & HDR & PK & & \\
\hline Acanthosaura armata & 0 & $\begin{array}{ll}1 \\
\end{array}$ & 0 & 0 & 0 & 1 & $\begin{array}{ll}0,6 \\
\end{array}$ \\
\hline Aphaniotis acutirostris & 15 & 10 & 0 & 12 & 0 & 37 & 21,1 \\
\hline Bronchocela cristatella & 0 & 1 & 1 & 0 & 2 & 4 & 2,3 \\
\hline Draco abbreviatus & 0 & 0 & 0 & 0 & 1 & 1 & 0,6 \\
\hline Draco melanopogon & 29 & 25 & 17 & 15 & 0 & 86 & 49,1 \\
\hline Draco o.obscurus & 5 & 0 & 3 & 0 & 0 & 8 & 4,6 \\
\hline Draco quinquefasciatus & 3 & 0 & 5 & 8 & 0 & 16 & 9,1 \\
\hline Draco sumatranus & 0 & 0 & 2 & 0 & 9 & 11 & 6,3 \\
\hline Gonocephalus grandis & 0 & 0 & 5 & 6 & 0 & 11 & 6,3 \\
\hline$\sum$ individu & 52 & 37 & 33 & 41 & 12 & 175 & 100 \\
\hline$\sum$ jenis & 4 & 4 & 6 & 4 & 3 & & \\
\hline Indeks diversitas (Shannon) & 1,074 & 0,814 & 1,407 & 1,328 & 0,721 & & \\
\hline Indeks kemerataan (Pielou) & 0,775 & 0,587 & 0,785 & 0,958 & 0,657 & & \\
\hline
\end{tabular}

Keterangan: $\mathrm{HP}=$ hutan primer, $\mathrm{HHC}=$ hutan hujan campuran, HTR = hutan terganggu ringan, HDR = hutan dataran rendah riparian dan $\mathrm{PK}=$ perkebunan karet.

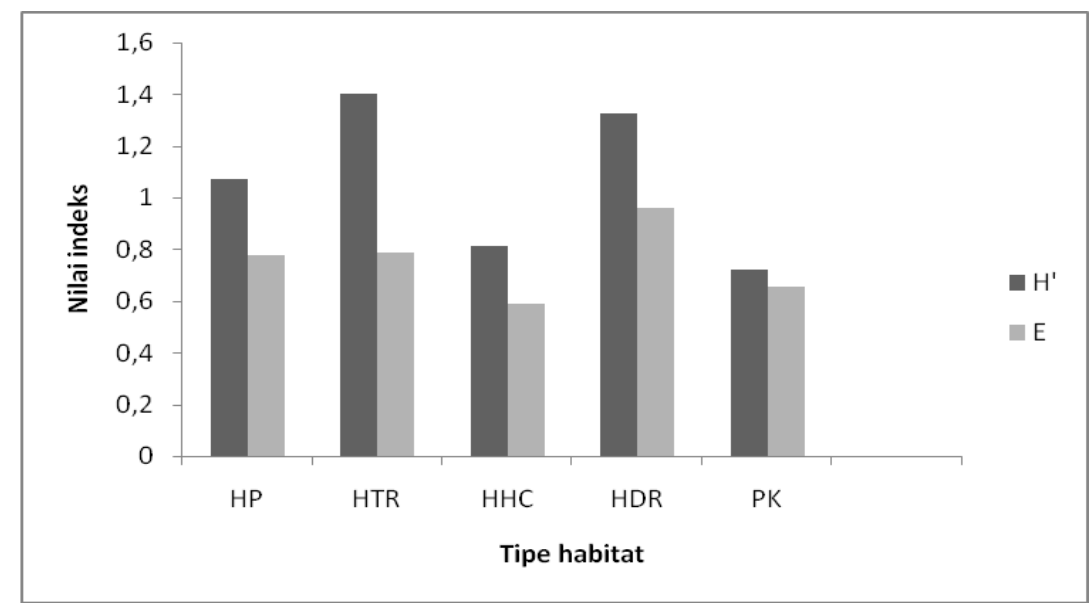

Gambar 1. Indeks diversitas $\left(\mathrm{H}^{\prime}\right)$ dan kemerataan (E) komunitas Agamidae pada lima tipe habitat di kawasan pertambangan emas Martabe antara Juli sampai Agustus 2008. HP = hutan primer, HHC = hutan hujan campuran, HTR = hutan terganggu ringan, $\mathrm{HDR}=$ hutan dataran rendah riparian dan $\mathrm{PK}=$ perkebunan. 
Fenomena ini dapat dijelaskan bahwa pada hutan terganggu ringan terdapat beberapa spot area yang relatif terbuka, pada spot-spot tersebut kemungkinan mengundang lebih banyak jenis serangga yang merupakan mangsa dari kelompok Agamidae. Dengan demikian jenisjenis Agamidae juga terkonsentrasi pada spotspot tersebut untuk memburu mangsanya. Spot area terbuka tersebut sangat terbatas dan diduga menjadi kondisi pendukung terjadinya kompetisi antar anggota Agamidae yang pada gilirannya terjadi dominasi jenis tertentu (D. melanopogon dan $A$. acutirostris). Kemungkinan lain adalah jumlah individu jenis serangga pada area terbuka tidak merata sehingga jumlah individu jenis pemangsa dalam hal ini Agamidae juga menjadi tidak merata.

\section{Pengelompokan Tipe Habitat}

Hasil perhitungan nilai indeks Sorensen yang merupakan penggambaran derajat kesamaan dua komunitas disajikan dalam Tabel 3, sedangkan hasil uji pengelompokannya disajikan pada Gambar 2.

Derajat kesamaan komunitas tertinggi terjadi antara hutan primer dan hutan dataran rendah riparian sebesar $75 \%$. Kedua tipe habitat tersebut sama sekali tidak mempunyai kesamaan dengan habitat perkebunan, derajat kesamaan masing-masing terhadap habitat perkebunan adalah 0\%. Derajat kesamaan tertinggi dari tipe habitat perkebunan hanya terjadi bila dibandingkan dengan hutan terganggu ringan, yaitu 44\%. Kecilnya derajat kesamaan dari habitat perkebunan dengan keempat tipe habitat lainnya ini, menyebabkan dalam uji pengelompokan habitat perkebunan terpisah tersendiri. Pada habitat perkebunan ini hanya dijumpai 3 jenis Agamidae saja, yaitu; Bronchocela cristatella, Draco abbreviatus dan Draco sumatranus. Hal ini terjadi kemungkinan disebabkan oleh kondisi perkebunan karet yang homogen dan relatif terbuka sehingga tidak mampu menyediakan ketersediaaan pakan dan penyusun habitat lainnya bagi banyak spesies Agamidae.

Berdasarkan Gambar 3 tampak bahwa dari lima tipe habitat yang diteliti, terdapat tiga kelompok tipe habitat, yaitu: (a) areal perkebunan (karet dan sedikit salak), (b) hutan terganggu ringan, hutan primer dan hutan dataran rendah riparian, serta (c) hutan hujan campuran.

Hutan primer dan hutan dataran rendah tergabung dalam satu kelompok, tetapi derajat kesamaannya hanya $75 \%$. Hal ini mengindikasikan bahwa komunitas Agamidae di kedua tipe habitat ini tidak sama dan selayaknya dipertahankan keduanya.

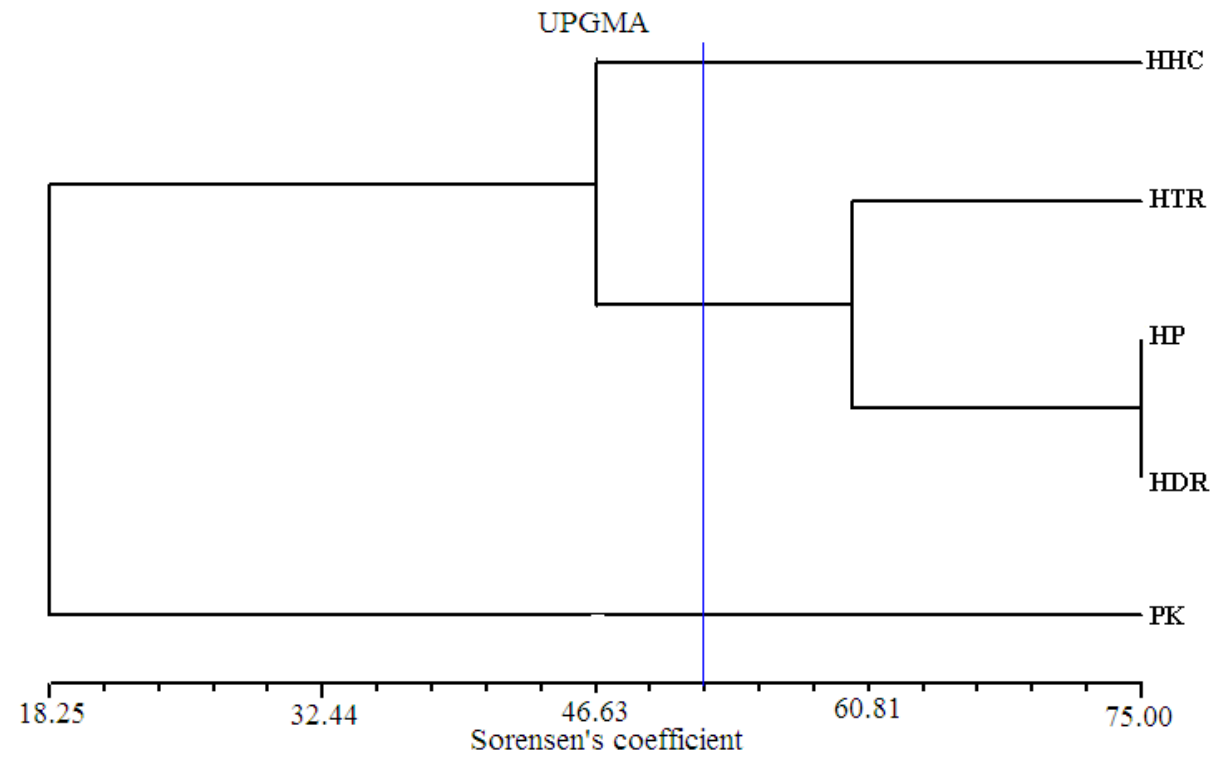

Gambar 2. Dendrogram kekerabatan antartipe habitat berdasarkan nilai indeks Sorensen di kawasan pertambangan emas Martabe pada periode Juli-Agustus 2008. HP = hutan primer, HHC = hutan hujan campuran, HTR $=$ hutan terganggu ringan, $\mathrm{HDR}=$ hutan dataran rendah riparian dan $\mathrm{PK}=$ perkebunan . 
Tabel 3. Derajat kesamaan antarkomunitas berdasarkan indeks kesamaaan Sorensen.

\begin{tabular}{lccccc}
\hline \hline \multicolumn{1}{c}{ Tipe Habitat } & $\begin{array}{c}\text { Hutan } \\
\text { Primer }\end{array}$ & $\begin{array}{c}\text { Hutan Hujan Hutan Terganggu } \\
\text { Campuran }\end{array}$ & $\begin{array}{c}\text { Hutan Dataran } \\
\text { Rendah Ran }\end{array}$ & Perkebunan \\
\hline Hutan primer & - & & & & \\
Hutan hujan campuran & 50 & - & & & \\
Hutan terganggu ringan & 60 & 40 & - & - & \\
Hutan dataran rendah riparian & 75 & 50 & 60 & 0 & - \\
Perkebunan & 0 & 29 & 44 & \\
\hline \hline
\end{tabular}

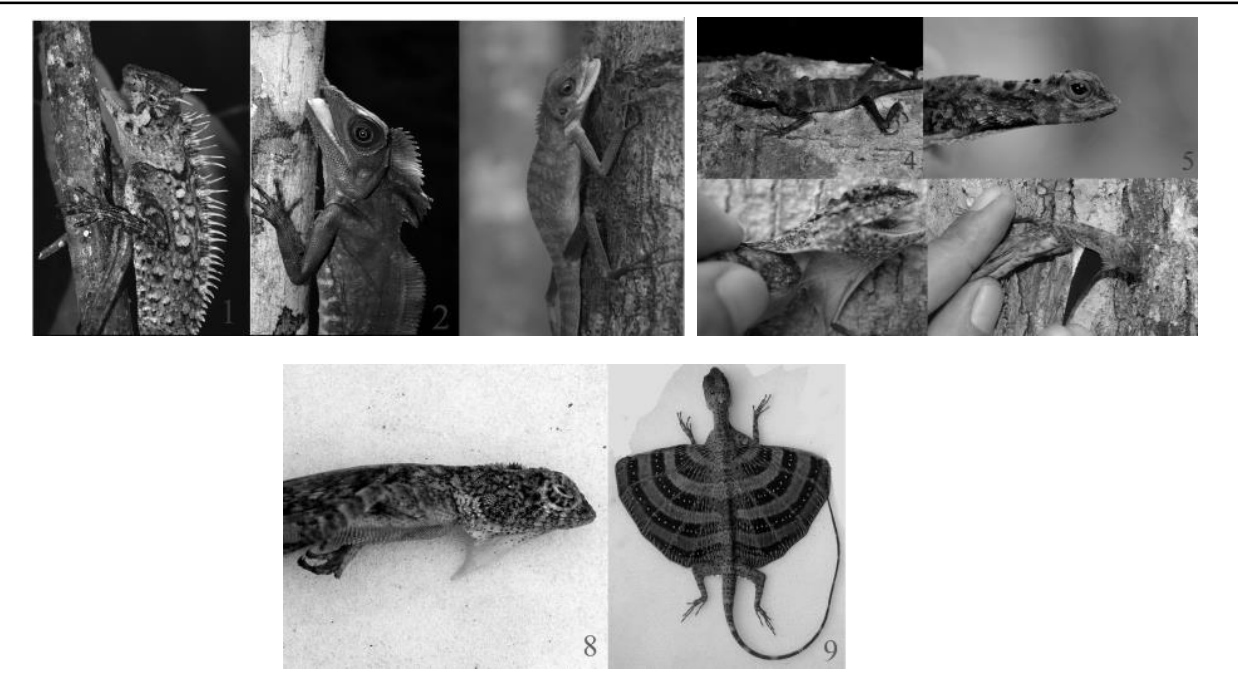

Gambar 3. Jenis Agamidae yang dijumpai di kawasan pertambangan emas Martabe dari Juli sampai Agustus 2008. (1) Acanthosaura armata (2) Gonocephalus grandis (3) Bronchocela cristatella (4) Aphaniotis acutirostris (5) Draco obscurus (6) D. abbreviatus (7) D. melanopogon (8) D. sumatranus (9) D. quinquefasciatus.

\section{Kunci Identifikasi}

Berikut ini dikemukakan kunci identifikasi berdasarkan karakter pembeda ke-9 jenis Agamidae yang dijumpai di kawasan pertambangan emas Martabe. Kunci identifikasi di bawah ini adalah setelah dimodifikasi dari Malkmus et al., (2002); Manthey dan Grossman (1997) dan Hallermann (2000).

1a Sisi badan dilengkapi dengan pelebaran kulit yang disokong rusuk (sayap semu)

2c Sayap semu berwarna kuning hingga oranye dengan 4-5 pita hitam melintang simetris, pada pita hitam terdapat spot warna putih Draco quinquefasciatus

2d Sayap semu berwarna hitam dengan bintik-bintik cokelat, punggung dihiasi pola bintik-bintik cokelat terang dan cokelat gelap yang simetris

Draco sumatranus

Pada tengkuk terdapat struktur sperti duri (nuchal spine)

5a Pada leher terdapat lipatan kulit, punggung dengan sisik rhomboid tanpa bercampur dengan sisik berukuran besar, lebar timpanum setengah diameter mata, punggung atas menunjuk kearah atas... Bronchocela cristatella 


\section{Simpulan dan Saran}

\section{Simpulan}

Sebanyak 9 jenis Agamidae dijumpai di kawasan Proyek Pertambangan Emas Martabe, Tapanuli Selatan, Sumatera Utara. $D$. melanopogon merupakan komponen utama penyusun komunitas Agamidae. Lima tipe habitat yang diteliti mengelompok menjadi habitat, yaitu: areal perkebunan, hutan terganggu ringan, dan hutan hujan campuran. Kesamaan komunitas tertinggi antara komunitas pada hutan primer dan hutan dataran rendah riparian.

\section{Saran}

Dengan menimbang relatif rendahnya kesamaan komunitas pada tipe habitat hutan primer dan hutan dataran rendah riparian $(75 \%)$, dan relatif tingginya indeks diversitas serta kemerataannya; maka sebaiknya pihak managemen MPA tidak mengorbankan salah satu di antaranya ketika melakukan aktivitas pertambangan.

\section{Ucapan Terima Kasih}

Penulis mengucapkan terima kasih kepada jajaran managemen Proyek Pertambangan emas Martabe-Sumatera Utara (Oxiana) atas izin dan dukungan penelitian ini. Terima kasih juga kepada Dr. Kate Martin (URS Corp) sebagai penyandang dana pada penelitian ini dan Bapak M. Yani (CBES, Mataram) dan Prof. Ibnu Maryanto (Puslit Biologi/MZB-LIPI) yang telah mempercayakan penelitian ini kepada penulis. Terima kasih juga ditujukan kepada Dr. Jimmy A. McGuire (Museum of Vertebrate Zoology, University of California Berkeley, USA) atas konsultasi mengenai marga Draco. Kepada bapak Misnan (staf lapangan divisi lingkungan Oxiana) yang telah mendampingi selama jalannya penelitian.

\section{Daftar Pustaka}

Bloomberg, S.B. dan Shine, R. 1996. Reptile. In: Sutherland, W.J. (Eds.). Ecological Census Techniques a Handbook. Pp: 218-226. Cambridge University Press. Cambridge.

Gillespie, G., Howard, S., Lockie, D., Scroggie, M. dan Boeadi. 2005. Herpetofaunal Richness and Community Structure of Offshore Islands of Sulawesi, Indonesia. Biotropica, 37 (2): 279290.

Hallermann, J. 2000. The Taxonomic status of Acanthosaura frustodferi Werner, 1904 and Calotes brevipes Werner, 1904 (Squamata: Agamidae). Mitt.Mus.Nat.kd. Berl. Zool. Reihe, 76 (1): 143-150.

Kurniati, H. 2007. The Herpetofauna of the Gold Mining Project Area in North Sumatra: Species Richness Before Exploitation Activities. Zoo Indonesia, 16 (1): 1-11.

Krebs, C.J. 1989. Ecological Methodology. Harper Collins publishers, University of British Columbia.

Ludwig, J.A. dan Reynolds, J.F. 1988. Statistical Ecology: A Primer on Methods and Computing. New York: John Willey and Sons.

Manthey, U. dan Grossmann, W. 1997. Amphibien and Reptilien Sudostasiens. Natur \& Tier-Verlag, Berlin.

McGuire, J.A. dan Heang, K.B. 2001. Phylogenetic systematics of Southeast Asian flying lizards (Iguania: Agamidae: Draco) as inferred from mitochondrial DNA sequence data. Biological J. of the Linnean Society, 72: 203-229.

Musters, C.J.M. 1983. Taxonomy of the genus Draco I. (Agamidae, lacertilia, Reptilia). Zoologische Verhandelingen No. 199. E.J. Brill Ltd. Leiden. $120 \mathrm{pp}$.

Pattiselanno, F. 2006. The Wildlife Hunting in Papua. Biota, XI (1): 59-61.

Rohlf, F.J. 2000. NTSYS-pc: Numerical Taxonomy and Multivariate Analysis System, v. 2.1. Exeter Software, New York.

Rooij, N.de. 1915. The Reptiles of The Indo Australian Archipelago I (Lacertilia, Chelonia, Emydosauria). E.I. Brill. Ltd. Leiden. 384 pp.

Wiratno, Indriyo, D., Syarifudin, A. dan Kartikasari, A. 2001. Berkaca Di Cermin Retak-Refleksi Konservasi dan Implikasi Bagi Pengelolaan Taman Nasional. Gibbon Foundation-PILINGO Movement. Jakarta. 